\title{
The influence of principal performance on teachers' pedagogical competence
}

Heru Siswanto ${ }^{1 *}$, Hasan Hariri ${ }^{2}$, Sowiyah Sowiyah ${ }^{3}$, Ridwan Ridwan ${ }^{4}$ SMP Negeri 1 Gadingrejo, Lampung, Pringsewu, Lampung, Indonesia ${ }^{1}$ Faculty of Teacher Training and Education, University of Lampung, Indonesia ${ }^{2,3}$ SMP Negeri 3 Way Pengubuan, Lampung Tengah, Lampung, Indonesia ${ }^{4}$ herusiswanto88@gmail.com

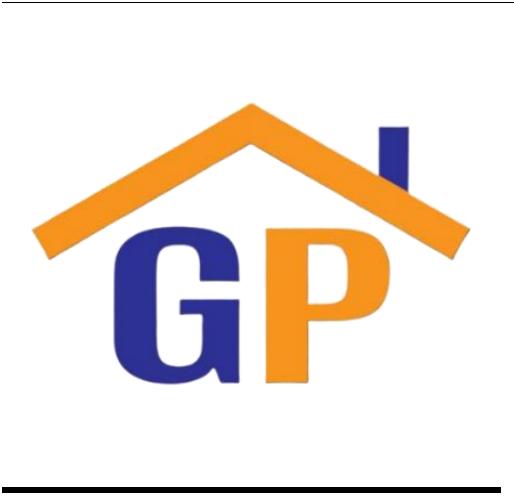

Article History

Received on 29 May 2020

$1^{\text {st }}$ Revision on 3 September 2020

$2^{\text {nd }}$ Revision on 24 September 2020

Accepted on 29 September 2020

\begin{abstract}
.
Purpose: The principal's job is very essential and governs the equal of student learning consequences. Principal performances are also in line with teachers' output and self-esteem. In this case, it can be said that the principal's working area creates a feeling of comfort for teachers. The principal performances create the feeling at home in encouraging teachers and employees to work in harmony with the rules and programs that have been delineated so that work output becomes great and pupil learning outcomes also upsurge. One of the teachers' productivity can be seen from the teachers' pedagogical proficiency. Pedagogical proficiency is a talent for understanding students and management of educational and dialogical learning. This study targets to determine in what way the impact of the principal's performance on teachers' pedagogical competence.
\end{abstract}

Research Methodology: The method used is the method of search and review. The review process starts with the search engine, Google scholar and reviewing related articles about principal performance and teachers' pedagogical competence.

Results: The results from 22 reviewed articles are that the role of the principal's performance is very influential in affecting the teacher's pedagogical competence.

Limitations: Since this study includes many cases, further research could include performing to analyze how principal performance could affect teacher pedagogical competence.

Contribution: This study can be useful in Faculty of Teacher Training and Education Lampung University and secondary education level

Keywords: Principal performance, Teachers' pedagogical competence, Responsibility

How to cite: Siswanto, H., Hariri, H., Sowiyah, S., Ridwan, R. (2020). The influence of principal performance on teachers' pedagogical competence. Journal of Social, Humanity, and Education, 1(1), 13-26.

\section{Introduction}

In terms of education, the learning outcome is the last thing that will happen after the process. The learning outcome comes from many aspects. The input of learning will take part in determining how well the quality will result. However, the input is not the only thing that determines the result. The learning process, as the main event of getting the result, takes the most important part in this case. In the learning process, it is known that every learning process requires many factors to be successful. Some of the factors are from teachers, students, and the environment. All processes need to be adjusted one to another to pull out the best result. Depending only to one factor will not give the best result. For example, a good environment without good teachers is not going to give a good result. But 
a bad environment and teachers with bad quality can be handled by a good school principal's performance. Principal performance is one important factor that affects teacher pedagogical competence (Minadzi \& Nyame, 2016). This indicates that every principal in educational institutions, including in Indonesian schools, needs to lead teachers professionally. A principal needs to behave in ways that make teachers happy (Hariri, Monypenny, \& Prideaux, 2016), and, accordingly, when being happy, they will work well and make a contribution to student achievement (Hariri, Monypenny, \& Prideaux, 2012; Hariri, Monypenny, \& Prideaux, 2013). In this case, teachers do what is expected of them, for example, creating an environment that enables school academic work. Therefore, one important factor in the success of the school for principals is the mastery of teachers' competences in managing the constructive and conducive classroom as the learning circumstances. Competence can be said to be an amalgamation of knowledge, skills and abilities. The teachers can gain these skills through a certain path. Competence is also the energy to execute any tasks based on knowledge, and capability (Makulova et al., 2015). In teaching, there are four main competences that should be mastered by teachers which are attitude, personality, pedagogical and professional. Competence is really important for teachers, especially pedagogical competence, because it is closely related to how teachers teach and will also relate to the outcome of students' learning results. Teachers with good pedagogical competence will tend to deliver subjects better than those who are not. However, it does not mean that other competencies are not important. Attitude competence will bring teachers to make a decision in class. Personality is a bit different where this competence presents as the way how the teacher behaves and acts as good teachers as they are working to be a role model. Professional is the competence where teachers put skills in term of his/her profession as a teacher. All of these competencies should be mastered by teachers. In this case, mastering it could be done as the process of working with different working situation, trainings and others.

The Teacher and Lecturer Law No. 14 of 2005 states that pedagogical aptitude is an ability with regard to the understanding of pupils and the management of learning that is educational and dialogic. This law outlined ten elements of teacher pedagogical competences: (1) Mastering student characteristics in all aspects inclusively; (2) Mastering the theory and teaching and learning principles; (3) Compiling a curriculum for the subjects that are taught; (4) Systematizing the process of learning ; (5) Employing internet technology to teach; (6) Facilitating the growth of the embryonic of students in order to achieve the actualization of their various potentials; (7) Communicating with students in an effective, compassionate and polite manner; (8) Carrying out process and learning outcomes assessment; (9) Making use of the assessment product for the learning; and (10) Taking reflective action to increase the value of learning (Pujiastuti, Raharjo, \& Widodo, 2012b). As can be seen above, the pedagogical competence contains many essential aspects which should be mastered by teachers. It is closely related to the learning process itself. No one could deny that sometimes teachers with good pedagogical competence are the ones that the schools need. Because without good pedagogical mastery, a teacher will not be able to convey the subject he/she is teaching to students. This will lead to bad subject comprehension or understanding, misunderstanding, wrong concept of learning and ineffective learning process. Although pedagogical competence can be trained and obtained in several ways, it is still not easy to gain competence which covers many teaching aspects above.

As mentioned previously, pedagogical is the competence which has to be mastered because it is closely related to how teachers change students' behavior from not knowing to knowing, from not understanding to understanding. Pedagogic competence is also important in communicating with students (Hakim, 2015). There has been an increase in research on competencies for continuous development. Many reviewed articles have proposed different pedagogical perspectives to provide better continuous improvement. Yet, pedagogical and competencies have, in general, been studied separately (Lozano, Merrill, Sammalisto, Ceulemans, \& Lozano, 2017). In this case, we know the method of pedagogy and the binary approach. In addition, evidence suggests that a pedagogical model setting with a binary perspective for optimization of influence and usage identification pedagogical to teach students to enables the teachers to make learning processes and outcomes more logical and, to some extent, resolves the logical of building a guaranteed quality system of professional education the binary-based (Telegina, Galimova, \& Masalimova, 2015). More importantly, there is a positive effect 
of pedagogical competence on the performance of junior high school science teachers in Ternate (Rahman, 2014). Pedagogic competence is related to the understanding grade of pupils, learning scheme, application of learning identification, and learning assessment. In this case, the growth of pupils has postulated noteworthy support in the form of professional pedagogic teaching. Teacher pedagogical competence has a significant impact on increased learning performance, especially in relation to mastery of teaching resources, learning problem-solving skills and assurance to do a decent job. A teacher also needs to possess social proficiency, that is, the skills linked with the power to make a relation, capability to survive with pupils, and all the school stakeholders. This competence can postulate in the shape of a social dexterity of teachers (Hakim, 2015).

Similar to the importance of teacher competence, school leadership is an important part of a school organization, but it is not the same as management. School leadership is in a wider scope than management. School leadership is important because it will affect how school management will run, how the leaders of the school will lead the school and of course it means it will affect the school quality as well. Leadership is the power of a person to stimulus people to accomplish school targets. Management includes functions such as planning, organizing, monitoring and evaluation to achieve school goals (Triyanto, Anitah, \& Suryani, 2013). Principals need to be good leaders to achieve goals effectively. Ekosiswoyo (2016) defined a good leader as one who has more traits than he leads; this advantage is a way of thinking, in harmony and in the body. A leader has the advantage of nobleness of character, the height of morality and simplicity of character. A leader always maintains good health so that he can carry out tasks and activities as well as the work implementation of the organization he leads. According to the leadership style, there are three types of leadership, namely (a) task-oriented leadership, can be seen from the quality of his desire to complete a task, (b) leadership oriented to work relations can be seen from the quality of work relations with others, both vertical and horizontal relationships, that is, relationships with subordinates, superiors and relationships with colleagues, and (c) leadership which is oriented towards effectiveness, can be seen from its ability to obtain high productivity. The third task-orientation will be realized if a leader is able to influence and move the mindset and behavior of the people he leads. In addition, Mbera (2015) stated that school principals face a multifaceted setting. They must change their roles to encounter the shifting external setting. They must manage the services offered to students and make certain that these services reach the students most in need while ensuring that there are no interruptions in the educational process. Iskandar (2013a) stated that the principal as the highest spearhead who is very powerful and governs the progress of the school must have administrative skills, high commitment, and flexibility in carrying out his obligations. Centered on the results of interviews with the supervisors of junior high schools in Lampung, Indonesia, as a preliminary study to get initial data, the authors of this article obtained information that: 1) There were still many complaints from teachers related to the management process carried out by the school principals, 2) The working atmosphere in some schools seems less conducive to affect the work environment of the teacher. 3) Not all schools implemented open management and involved all teachers, 4) There were only a few principals who gave awards to outstanding teachers, 5) Some teachers who had high work motivation because they felt they got attention from the school principals. Thus, the most appropriate question for this research is "How far does the principal's performance could affect teachers' pedagogical competence?" that will be answered by reviewing related articles to the topics.

\section{Literature review and hypothesis development}

\subsection{Performance}

Arum (2017a) defined performance simply as a result of measurable goal achievement. Performance is not only what is achieved by people but how they achieve it. High-performance results from appropriate behavior, especially behavioral wisdom, and effective use of required knowledge, skills and competencies. Furthermore, Andriani, Kesumawati, and Kristiawan (2018) clinched that performance is the effect or accomplishment of a person or organization in the form of doing, defining and creating something physically and non-physically in agreement with the directions and purposes. Tasks are based on knowledge, attitudes, skills and motivation. Performance issues always get notification in management since they are very closely related to the institution's performance. Mainly 
it affects willpower and performance. Indeed, many people can do the job, but they do not necessarily want to do the job, so it does not produce a good performance. Performance is something that a person achieves or the attainment/ability exhibited by a person or group to meet its achievement goals and intentions. Furthermore, Putra, Perizade, Sulastri, and Hanafi (2019) state that antecedent performance is to achieve productivity because performance is a combination of people and assets in institutions to achieve the final goal accordance with the level of excellence and ideals they have done well.

\subsection{Principal's performance}

According to Purwaningsih (2019) the principal is an educator who has the power to be the chief and accomplishes all means in a school so that all these assets can be outstandingly employed to attain shared ends. Achievement principals postulate tiring work morale which aims to increase teacher work output and improve student learning outcomes. The principal's accountability is very significant and determines the value of student learning consequences. On the other hand, teacher throughput and self-esteem depend on the principal. In this case, it means the extent to which the principal can construct joy at work and the range to which the school can inspire colleagues to effort in agreement with the policies and programs that have been sketched. This makes teacher work throughout elevated and student learning results growth.

Putra et al. (2019) enlightened that there are five vital dimensions of principal functioning. They are (1) Building a common goal. Here the leader progresses an organizational vision that pulls together and safeguards a vivid vision in the educator's day-to-day work; (2) Focusing on learning. In this case the leader occupies in teaching headship to progress and preserve student access to appropriate, striving, and resilient teaching programs that are attentive on schooling fineness and development of social and emotional; (3) Organizing the resources the organization has. Leaders make use of strategically and thoroughly to generate benign and supportive surroundings for educational activities by utilizing the monetary, human, data, and all assets; (4) Collaborating with the community. Here the leader keeps parents and community organizations in a tangle with the school; (5) Leading with honesty. Exemplary professional leaders who act reliably and always have a desire to learn so that it can be concluded that a school principal is obliged not only to have a foundation of talent and knowledge that is in accordance with his duties as principal but also must have emotional intelligence which will guide him to develop rapidly in leading the school.

\subsection{Teacher's pedagogical competence}

A teacher must possess talents in accordance with Law Number 19 of 2005 concerning National Education Standards, namely pedagogical competence, personality competence, professional competence, and social competence. Several previous analyzes have proven that talent is related to business performance and individual performance in the profession. In this case, however, the focus remains on pedagogical competence. Hakim (2015) argues that pedagogical competence related to student acceptance rates, learning plans, and use of learning, decisions, learning evaluation, and student development has provided support that needs attention in the form of professional pedagogic teaching. Teachers are said to fulfill professional knowledge and skills as well as pedagogical knowledge if they master the subject matter in a well-adjusted manner because problems that arise in the learning process cannot be solved with just one of these skills. Professional and pedagogical competences support each other. The teacher will provide subject matter to students well and it can be accepted if the teacher plans the learning process properly according to student needs and carries out learning using various learning methods/strategies.

Astuty (2015) states that pedagogical abilities include sub-competencies (1) Accepting the individuality of students from physical, social, moral, cultural, emotional, and intellectual aspects; (2) Understand the student's family and city background and the students' needs in a cultural environment; (3) Understanding the various complications of learning and learning; (4) Accelerate the development of student potential; (5) Understand the theories and principles of enlightening learning and learning; 6. Developing a curriculum that encourages student participation in learning; (7) Designing educational learning; (8) Carry out educational learning; (9) Evaluating the learning 
process and results. Rahman (2014) defines teacher pedagogical abilities as the ability to manage learning which includes planning, implementing, and assessing student learning outcomes. Pedagogic competence is "the ability of students to carry out learning". This competence can be seen from the ability to design teaching and learning courses, the ability to cooperate or manage the learning process, and the ability to carry out evaluations (Akhyak, 2013).

\section{Research methodology}

This literature review focuses on the influence of the principal's performance on teacher's pedagogic competency. Thus, this literature review is built by gathering and filtering researches under these following conditions and search keys:

a. Performance: 1.050 .000 results

b. Principal's performance: 16.700 results

c. Competence: 622.000 results

d. Teachers pedagogical competence: 17.700 results

e. Range of research year between 2015-2020

Thus, from the method above, the author found 22 closely related articles. The author decided to choose those articles because the 22 articles have similarities in terms of the main topic, which is related to the school principal's performance.

Table 1: The Impact of Principal's Performance on Teachers Pedagogic Competency

\begin{tabular}{|c|c|c|c|c|c|}
\hline $\begin{array}{c}\text { Author and } \\
\text { Year }\end{array}$ & Title & Country & Method & Sample & Results \\
\hline$\frac{\text { Ekosiswoyo }}{\underline{(2016)}}$ & $\begin{array}{c}\text { Effective } \\
\text { Principal } \\
\text { Leadership: A } \\
\text { Key to } \\
\text { Attaining } \\
\text { Education } \\
\text { Quality }\end{array}$ & Indonesia & Qualitative & $\begin{array}{l}\text { Principal's } \\
\text { Leadership } \\
\text { Style }\end{array}$ & $\begin{array}{l}\text { The leadership } \\
\text { factor is very } \\
\text { important in } \\
\text { supporting the } \\
\text { process of } \\
\text { improving the } \\
\text { quality of } \\
\text { education because } \\
\text { the style or } \\
\text { behavior } \\
\text { characteristics } \\
\text { shown by the } \\
\text { leader will } \\
\text { influence and } \\
\text { move individuals } \\
\text { or groups in the } \\
\text { organization they } \\
\text { lead. }\end{array}$ \\
\hline$\underline{\text { Sartono and }}$ & $\begin{array}{c}\text { Are the } \\
\text { sections } \\
\text { problematic? } \\
\text { A case study } \\
\text { at Elementary } \\
\text { School } 033 \\
\text { Asmi }\end{array}$ & Indonesia & Qualitative & $\begin{array}{c}\text { Material } \\
\text { about } \\
\text { fractions in } \\
\text { Mathematics }\end{array}$ & $\begin{array}{l}\text { (1) Students have } \\
\text { difficulty } \\
\text { understanding } \\
\text { fractions; (2) The } \\
\text { students' } \\
\text { difficulties } \\
\text { regarding } \\
\text { fractions, namely } \\
\text { the difficulty of } \\
\text { converting } \\
\text { fractions into } \\
\text { mixed fractions to } \\
\text { be uncommon, }\end{array}$ \\
\hline
\end{tabular}




\begin{tabular}{|c|c|c|c|c|c|}
\hline & & & & & $\begin{array}{l}\text { difficulties in } \\
\text { multiplying } \\
\text { fractions, and } \\
\text { difficulties in } \\
\text { matching } \\
\text { operations between } \\
\text { fractions and } \\
\text { whole numbers. }\end{array}$ \\
\hline$\underline{\text { Aiko (2015) }}$ & $\begin{array}{c}\text { The } \\
\text { relationship } \\
\text { between the } \\
\text { Leadership } \\
\text { Style practiced } \\
\text { by the } \\
\text { Principal of } \\
\text { Public Middle } \\
\text { Schools and } \\
\text { Student } \\
\text { Academic } \\
\text { Performance }\end{array}$ & Kenya & Quantitative & $\begin{array}{l}\text { Around119 } \\
\text { principals and } \\
2380 \text { teachers } \\
\text { employed in } \\
\text { the } 119 \\
\text { public } \\
\text { secondary } \\
\text { schools at } \\
\text { Kericho } \\
\text { District } \\
\text { Education } \\
\text { Office }\end{array}$ & $\begin{array}{l}\text { The study looked } \\
\text { at general } \\
\text { leadership } \\
\text { intelligence shown } \\
\text { by principals in } \\
\text { Kericho District as } \\
\text { democratic. A } \\
\text { further finding was } \\
\text { that there was no } \\
\text { significant change } \\
\text { in perceptions of } \\
\text { the principal's } \\
\text { leadership style as } \\
\text { assessed by } \\
\text { principals and } \\
\text { teachers. }\end{array}$ \\
\hline$\frac{\text { Iskandar }}{\underline{(2013 a)}}$ & $\begin{array}{l}\text { Principal } \\
\text { Leadership in } \\
\text { Improving } \\
\text { Teacher } \\
\text { Performance } \\
\end{array}$ & Indonesia & Qualitative & $\begin{array}{l}\text { Principal's } \\
\text { Leadership } \\
\text { Style }\end{array}$ & $\begin{array}{l}\text { The principal's } \\
\text { duty as a manager } \\
\text { is to evaluate } \\
\text { teacher } \\
\text { performance. }\end{array}$ \\
\hline Akhyak (2013) & $\begin{array}{l}\text { Application of } \\
\text { Teachers } \\
\text { Pedagogy } \\
\text { Competence to } \\
\text { Optimizing } \\
\text { Learners } \\
\text { Development } \\
\text { in Public } \\
\text { Primary } \\
\text { School in } \\
\text { Indonesia }\end{array}$ & Indonesia & Qualitative & $\begin{array}{l}\text { Department } \\
\text { of Education } \\
\text { officials in } \\
\text { Yogyakarta, } \\
\text { Tulung } \\
\text { Agung, and } \\
\text { Surabaya }\end{array}$ & $\begin{array}{l}\text { The strengths or } \\
\text { weaknesses of the } \\
\text { intellectual } \\
\text { functioning of } \\
\text { students in public } \\
\text { primary schools in } \\
\text { Indonesia have } \\
\text { been documented } \\
\text { by mainstream } \\
\text { teachers. Good } \\
\text { nutrition can } \\
\text { postulate energy } \\
\text { for students to } \\
\text { strengthen their } \\
\text { academic } \\
\text { improvement. }\end{array}$ \\
\hline $\begin{array}{c}\text { Bhutto and } \\
\text { Dehraj (2018) }\end{array}$ & $\begin{array}{l}\text { Developing } \\
\text { Process in } \\
\text { Leadership } \\
\text { Performance } \\
\text { of Secondary } \\
\text { School Head } \\
\text { Teachers In } \\
\text { District } \\
\text { Shaheed }\end{array}$ & Pakistan & Quantitative & $\begin{array}{l}20 \text { secondary } \\
\text { school's head } \\
\text { teachers }\end{array}$ & $\begin{array}{l}\text { This is indicated } \\
\text { by the principal } \\
\text { who spends most } \\
\text { of his spare time } \\
\text { on conductive } \\
\text { things that occur, } \\
\text { from government } \\
\text { enforcement and } \\
\text { subsidizing }\end{array}$ \\
\hline
\end{tabular}




\begin{tabular}{|c|c|c|c|c|c|}
\hline & Benazirabad & & & & $\begin{array}{l}\text { administrative } \\
\text { matters to } \\
\text { improving the } \\
\text { quality and success } \\
\text { of schools. }\end{array}$ \\
\hline $\begin{array}{c}\frac{\text { Pujiastuti, }}{\text { Raharjo, and }} \\
\text { Widodo (2012a) }\end{array}$ & $\begin{array}{c}\text { Kompetensi } \\
\text { profesional, } \\
\text { pedagogik } \\
\text { guru IPA, } \\
\text { persepsi siswa } \\
\text { tentang proses } \\
\text { pembelajaran, } \\
\text { dan } \\
\text { kontribusinya } \\
\text { terhadap hasil } \\
\text { belajar IPA di } \\
\text { SMP/MTs } \\
\text { Kota } \\
\text { Banjarbaru. } \\
\text { Innovative } \\
\text { Journal of } \\
\text { Curriculum } \\
\text { and } \\
\text { Educational } \\
\text { Technology, } \\
\text { l(1). }\end{array}$ & Indonesia & Quantitative & $\begin{array}{l}\text { All Science } \\
\text { Teachers } \\
\text { teaching in } \\
\text { the } 9^{\text {th }} \text { grade } \\
\text { and } 9^{\text {th }} \text { grade } \\
\text { students in } \\
\text { Banjarbaru }\end{array}$ & $\begin{array}{l}\text { Teachers are also } \\
\text { expected to guide } \\
\text { students to become } \\
\text { independent } \\
\text { learners, so as to } \\
\text { minimize the } \\
\text { consequences of } \\
\text { teacher skills on } \\
\text { student learning } \\
\text { outcomes. Students } \\
\text { have a good } \\
\text { perception of the } \\
\text { learning process } \\
\text { carried out by } \\
\text { science teachers; } \\
\text { Teachers should } \\
\text { try to collect the } \\
\text { benefits they get to } \\
\text { become more } \\
\text { meaningful. }\end{array}$ \\
\hline$\frac{\text { Purwaningsih }}{\underline{(2019)}}$ & $\begin{array}{c}\text { Influence of } \\
\text { School Head } \\
\text { Leadership on } \\
\text { Teacher and } \\
\text { Administrative } \\
\text { Staff } \\
\text { Performance } \\
\text { in SMP N 1 } \\
\text { Baturaden in } \\
\text { The School } \\
\text { Year 2018- } \\
2019\end{array}$ & Indonesia & Quantitative & 39 teachers & $\begin{array}{l}\text { The principal of } \\
\text { SMP Negeri } 1 \\
\text { Baturaden has the } \\
\text { talent to inspire } \\
\text { teachers and } \\
\text { secretarial staff to } \\
\text { become role } \\
\text { models in } \\
\text { leadership } \\
\text { behavior and have } \\
\text { adequate abilities } \\
\text { to manage } \\
\text { situations. }\end{array}$ \\
\hline$\frac{\text { Mirzagitova and }}{\frac{\text { Akhmetov }}{\underline{(2015)}}}$ & $\begin{array}{c}\text { Self- } \\
\text { Development } \\
\text { of Pedagogical } \\
\text { Competence } \\
\text { of Future } \\
\text { Teacher }\end{array}$ & Russia & Qualitative & $\begin{array}{l}\text { Pedagogical } \\
\text { Competence }\end{array}$ & $\begin{array}{l}\text { The educational } \\
\text { atmosphere at the } \\
\text { University of } \\
\text { Education in } \\
\text { Russia corresponds } \\
\text { to the features of } \\
\text { the creation of the } \\
\text { professional } \\
\text { proficiency of } \\
\text { future teachers } \\
\text { when: trained } \\
\text { restraint content is } \\
\text { not only } \\
\text { interesting, but } \\
\text { also pays attention }\end{array}$ \\
\hline
\end{tabular}




\begin{tabular}{|c|c|c|c|c|c|}
\hline & & & & & to run-throughs \\
\hline$\underline{\text { Hakim }(2015)}$ & $\begin{array}{c}\text { Contribution } \\
\text { of } \\
\text { Competence } \\
\text { Teacher } \\
\text { (Pedagogical, } \\
\text { Personality, } \\
\text { Professional } \\
\text { Competence } \\
\text { and Social) On } \\
\text { the } \\
\text { Performance } \\
\text { of Learning }\end{array}$ & Indonesia & Quantitative & $\begin{array}{c}117 \text { faculty } \\
\text { spread of } 25 \\
\text { high schools }\end{array}$ & $\begin{array}{l}\text { Pedagogic, } \\
\text { individual, } \\
\text { professional and } \\
\text { social } \\
\text { competencies } \\
\text { collectively have } \\
\text { important } \\
\text { consequences in } \\
\text { increasing learning } \\
\text { achievement }\end{array}$ \\
\hline$\underline{\text { Rahman (2014) }}$ & $\begin{array}{c}\text { Professional } \\
\text { Competence, } \\
\text { Pedagogical } \\
\text { Competence } \\
\text { and the } \\
\text { Performance } \\
\text { of Junior High } \\
\text { School of } \\
\text { Science } \\
\text { Teachers }\end{array}$ & Indonesia & Quantitative & $\begin{array}{l}61 \text { science } \\
\text { teachers }\end{array}$ & $\begin{array}{l}\text { The more } \\
\text { advanced the } \\
\text { professional } \\
\text { competence of the } \\
\text { teacher, the more } \\
\text { developed the } \\
\text { teacher's } \\
\text { performance. } \\
\text { Science teacher } \\
\text { professional } \\
\text { proficiency can be } \\
\text { improved through } \\
\text { their performance. }\end{array}$ \\
\hline Astuty (2015) & $\begin{array}{l}\text { Implementatio } \\
\text { n Analysis of } \\
\text { Lecturer's } \\
\text { Pedagogical } \\
\text { Competence } \\
\text { on Student's } \\
\text { Academic } \\
\text { Achievement }\end{array}$ & Indonesia & Quantitative & $\begin{array}{c}\text { Lecturer's } \\
\text { competence + } \\
96 \text { students } \\
\text { GPA }\end{array}$ & $\begin{array}{l}\text { The results showed } \\
\text { that if the four } \\
\text { teacher } \\
\text { competencies, } \\
\text { namely pedagogy, } \\
\text { personality, } \\
\text { professionalism, } \\
\text { and manner, were } \\
\text { smeared discretely. } \\
\text { Of these, only } \\
\text { pedagogical } \\
\text { proficiency has a } \\
\text { momentous effect } \\
\text { on pupil academic } \\
\text { attainment. }\end{array}$ \\
\hline $\begin{array}{c}(\text { Minadzi \& } \\
\text { Nyame, } 2016)\end{array}$ & $\begin{array}{c}\text { Leadership } \\
\text { Styles Of } \\
\text { Basic School } \\
\text { Head } \\
\text { Teachers: } \\
\text { How Does It } \\
\text { Influence } \\
\text { Teachers' } \\
\text { Classroom } \\
\text { Performance? }\end{array}$ & Ghana & Quantitative & $\begin{array}{c}94 \text { schools } \\
\text { with teacher } \\
\text { population of } \\
919 \\
\text { (accessible } \\
\text { population) }\end{array}$ & $\begin{array}{l}\text { Basic school } \\
\text { teachers in the } \\
\text { South Tongu } \\
\text { District largely } \\
\text { agreed that the } \\
\text { behavior of their } \\
\text { head teachers had } \\
\text { some influence on } \\
\text { their classroom } \\
\text { performance. }\end{array}$ \\
\hline$\frac{\text { Andryukhina et }}{\underline{\text { al. (2016) }}}$ & $\begin{array}{c}\text { The Model of } \\
\text { Monitoring of } \\
\text { Vocational }\end{array}$ & Russia & Qualitative & $\begin{array}{l}\text { Pedagogical } \\
\text { Competences } \\
\text { of Professors }\end{array}$ & $\begin{array}{l}\text { The practical } \\
\text { implication of the } \\
\text { results of this study }\end{array}$ \\
\hline
\end{tabular}




\begin{tabular}{|c|c|c|c|c|c|}
\hline & $\begin{array}{c}\text { Pedagogical } \\
\text { Competences } \\
\text { of Professors } \\
\text { in Secondary } \\
\text { Vocational } \\
\text { Education }\end{array}$ & & & $\begin{array}{l}\text { in Secondary } \\
\text { Vocational } \\
\text { Education }\end{array}$ & $\begin{array}{l}\text { is the development } \\
\text { of models and } \\
\text { supervision tools. }\end{array}$ \\
\hline$\frac{\text { Lozano et al. }}{\underline{(2017)}}$ & $\begin{array}{c}\text { Connecting } \\
\text { Competences } \\
\text { and } \\
\text { Pedagogical } \\
\text { Approaches } \\
\text { for Sustainable } \\
\text { Development } \\
\text { in Higher } \\
\text { Education: A } \\
\text { Literature } \\
\text { Review and } \\
\text { Framework } \\
\text { Proposal }\end{array}$ & Sweden & Qualitative & $\begin{array}{c}\text { Proficiencies } \\
\text { and } \\
\text { Pedagogical } \\
\text { Methods }\end{array}$ & $\begin{array}{l}\text { In order for the } \\
\text { mindsets and } \\
\text { engagements of } \\
\text { forthcoming } \\
\text { cohorts to develop } \\
\text { better, we must } \\
\text { stipulate a 'full } \\
\text { month' (i.e., a } \\
\text { wide-ranging } \\
\text { customary) of } \\
\text { sustainability } \\
\text { competencies. }\end{array}$ \\
\hline$\frac{\text { (Makulova et }}{\underline{\text { al., 2015) }}}$ & $\begin{array}{l}\text { Theory and } \\
\text { Practice of } \\
\text { Competency- } \\
\text { Based } \\
\text { Approach in } \\
\text { Education }\end{array}$ & Kazakhstan & Qualitative & $\begin{array}{c}\text { Competency- } \\
\text { Based } \\
\text { Approach }\end{array}$ & $\begin{array}{l}\text { In the assumption, } \\
\text { it must be } \\
\text { distinguished that } \\
\text { competent } \\
\text { educational } \\
\text { approaches are } \\
\text { being developed in } \\
\text { different countries, } \\
\text { in different ways. }\end{array}$ \\
\hline$\frac{\text { (Masalimova, }}{\text { Galimova, \& }}$ & $\begin{array}{l}\text { The structure } \\
\text { and content of } \\
\text { the model of } \\
\text { pedagogical } \\
\text { conditions } \\
\text { binary } \\
\text { approach to } \\
\text { optimization } \\
\text { of control and } \\
\text { diagnostic } \\
\text { functions in } \\
\text { teaching } \\
\text { "general } \\
\text { pedagogy" to } \\
\text { students. }\end{array}$ & Russia & Qualitative & $\begin{array}{l}\text { Pedagogical } \\
\text { Conditions } \\
\text { Binary } \\
\text { Approach's } \\
\text { Structure and } \\
\text { Content }\end{array}$ & $\begin{array}{l}\text { Pedagogical } \\
\text { situation models } \\
\text { that use a binary } \\
\text { approach to event } \\
\text { optimization and } \\
\text { identification } \\
\text { controls to teach } \\
\text { students "general } \\
\text { pedagogy" allow } \\
\text { you to make } \\
\text { learning processes } \\
\text { and outcomes } \\
\text { more effective }\end{array}$ \\
\hline$\frac{\frac{\text { Wadesango, }}{\text { Gudyanga, and }}}{\frac{\text { Mberewere }}{(2015)}}$ & $\begin{array}{c}\text { Occupational } \\
\text { Stress among } \\
\text { School Head } \\
\text { Teachers: A } \\
\text { Case for } \\
\text { Hwedza } \\
\text { District } \\
\text { Secondary } \\
\text { Schools' Head } \\
\text { Teachers }\end{array}$ & $\begin{array}{l}\text { United } \\
\text { Kingdom }\end{array}$ & $\begin{array}{l}\text { Mixed } \\
\text { Methods }\end{array}$ & $\begin{array}{c}30 \text { school } \\
\text { principals and } \\
30 \text { secondary } \\
\text { school } \\
\text { teachers in } \\
\text { the Hwedza } \\
\text { area }\end{array}$ & $\begin{array}{l}\text { Psychologically, } \\
\text { the principal } \\
\text { admitted that they } \\
\text { had felt anxious, } \\
\text { bored, frustrated, } \\
\text { depressed, guilty, } \\
\text { ashamed and } \\
\text { inferior. The } \\
\text { impact of this } \\
\text { feeling is the } \\
\text { inefficient and }\end{array}$ \\
\hline
\end{tabular}




\begin{tabular}{|c|c|c|c|c|c|}
\hline & & & & & $\begin{array}{l}\text { ineffective } \\
\text { performance of the } \\
\text { principal. }\end{array}$ \\
\hline$\frac{\text { Andriani et al. }}{\underline{(2018)}}$ & $\begin{array}{l}\text { The Influence } \\
\text { of The } \\
\text { Transformatio } \\
\text { nal Leadership } \\
\text { And Work } \\
\text { Motivation On } \\
\text { Teachers } \\
\text { Performance }\end{array}$ & Indonesia & Quantitative & 193 teachers & $\begin{array}{l}\text { Transformational } \\
\text { headship has a } \\
\text { momentous } \\
\text { consequence on } \\
\text { the performance of } \\
\text { SMK teachers in } \\
\text { Palembang. The } \\
\text { better the } \\
\text { transformational } \\
\text { leadership, the } \\
\text { better the } \\
\text { performance of } \\
\text { SMK teachers in } \\
\text { Palembang. }\end{array}$ \\
\hline$\frac{\text { Putra et al. }}{\underline{(2019)}}$ & $\begin{array}{c}\text { The } \\
\text { Knowledge } \\
\text { Transfer And } \\
\text { The } \\
\text { Performance } \\
\text { of The } \\
\text { Principal At } \\
\text { State High } \\
\text { Schools And } \\
\text { State } \\
\text { Vocational } \\
\text { High Schools } \\
\text { In South } \\
\text { Sumatera } \\
\text { Province, } \\
\text { Indonesia }\end{array}$ & Indonesia & Quantitative & $\begin{array}{c}167 \\
\text { Principals }\end{array}$ & $\begin{array}{l}\text { The process of } \\
\text { obtaining } \\
\text { transmission } \\
\text { consisting of } \\
\text { socialization, } \\
\text { externalization, } \\
\text { merging, and } \\
\text { internalization of } \\
\text { the role of the } \\
\text { principal will } \\
\text { increase the role of } \\
\text { the principal in } \\
\text { building common } \\
\text { goals, managing } \\
\text { organizational } \\
\text { resources, working } \\
\text { with communities, } \\
\text { and especially with } \\
\text { reliability. }\end{array}$ \\
\hline$\underline{\operatorname{Arum}(2017 \mathrm{~b})}$ & $\begin{array}{c}\text { The } \\
\text { Development } \\
\text { of Elementary } \\
\text { School } \\
\text { Principal's } \\
\text { Managerial } \\
\text { Performance } \\
\text { Assessment } \\
\text { Model Based } \\
\text { on } \\
\text { Competence } \\
\text { Standard }\end{array}$ & Indonesia & $\mathrm{RnD}$ & $\begin{array}{l}\text { Managerial } \\
\text { Performance } \\
\text { Assessment } \\
\text { Model }\end{array}$ & $\begin{array}{l}\text { The Development } \\
\text { of Principal } \\
\text { Managerial } \\
\text { Performance } \\
\text { Assessment Model } \\
\text { instrument needs } \\
\text { to be done so that } \\
\text { the assessment of } \\
\text { the principal really } \\
\text { measures all } \\
\text { measured aspects } \\
\text { and the process of } \\
\text { processing results } \\
\text { is fast, thus it is } \\
\text { necessary to } \\
\text { improve the model } \\
\text { of principal } \\
\text { managerial }\end{array}$ \\
\hline
\end{tabular}




\begin{tabular}{|c|c|c|c|c|c|}
\hline & & & & & $\begin{array}{l}\text { performance } \\
\text { assessment }\end{array}$ \\
\hline$\frac{\text { Patimah }}{\underline{(2018 b)}}$ & $\begin{array}{l}\text { Management } \\
\text { Performance } \\
\text { in Islamic } \\
\text { Senior High } \\
\text { School } \\
\text { Education: An } \\
\text { Empirical } \\
\text { Study }\end{array}$ & Indonesia & Quantitative & 30 Principals & $\begin{array}{l}\text { The relationship } \\
\text { between emotional } \\
\text { intelligence and } \\
\text { the performance of } \\
\text { MTs Principals is } \\
\text { constructive and } \\
\text { deserves attention. } \\
\text { Emotional } \\
\text { intelligence is a } \\
\text { competency that } \\
\text { must be possessed } \\
\text { by a madrasa } \\
\text { principal. }\end{array}$ \\
\hline
\end{tabular}

\section{Results and discussions}

Centered on the upshots of literature reviews and reviews from sources obtained, the analysis shows that most of the articles focus on how the principal's performance influences teacher pedagogical competence. As can be seen from the articles reviewed that most the role of the Principal's performance is very influential in the teacher pedagogical competence. High achieving principals are trained in various institutions and in various curricula. A distributed leadership curriculum supports, evaluates and develops the teachers' excellence, goal setting, valuation and liability, strategic finance and human means controlling, and networking alongside other institutions (Bhutto \& Dehraj, 2018). Although there are other factors that can affect teachers' pedagogical competency like leadership styles, approaches, knowledge transfers and other professional competences, in this case, pedagogical competence is the most affected one among other competencies. The sets of skills a school principal must have will directly affect the result as teachers' pedagogical competence. This means, the school principal's performance has a very big impact on the school's quality. This is because the school principal's performance will definitely affect how the management run and of course, will lead to how the teachers' quality. The teachers' quality itself will also directly connect to the students' quality since teachers with good pedagogical competence will also convey their subjects in the most comprehensive ways.

On the other hand, according to Akhyak (2013), a pedagogy which can be seen as independent competence plays an important role in the preparation of the learning process to the evaluation of the process. This pedagogical competence is closely related to students' communication ability as the final result of the expected data in the related researches. For example, the strengths or weaknesses of the intellectual function of students in public elementary schools in Indonesia have been acknowledged by the bulk of teachers. Good food can stipulate liveliness for students to strengthen their intellectual development. Rahman (2014) defines which that nutrition comes from knowledge transfer and only a teacher with good pedagogical competence can give such treatment. If the four teacher competencies (pedagogic, personality, professional, and attitude) are pertained separately, only the pedagogic aptitudes have a noteworthy effect on student academic attainment. The duty of the principal as a manager is to do the scoring on teachers' performance (Iskandar, 2013b). This also means that the principal has the biggest impact on evaluating teachers' pedagogical competence. Thus, the principal is the one responsible for developing teachers' pedagogical competence. Based on the findings above, we can take the broad conclusion that the school principal's performance could influent teachers' pedagogical competence significantly.

\section{Conclusion}

After the review of 22 articles and analyzing to get the findings, the conclusion of the research is that the principal's performance can affect teachers' pedagogical competence and The duty of principal as a manager is to do scoring on teachers' performance (Iskandar, 2013b). Nevertheless, doing such an 
evaluation to do scoring on teachers' performance is not easy. If it is not done carefully, it will have a bad impact. For example, psychologically, the principal admitted that they had felt anxious, bored, frustrated, depressed, guilty, ashamed and inferior. The impact of this feeling is the inefficient and ineffective performance of the principal (Wadesango et al., 2015). As also stated by Andriani et al. (2018), that the transformational headship has a consequence meaningfully to the enactment of SMK teachers in Palembang. The better of the transformational leadership is the more performance of SMK teachers in Palembang. This supports the conclusion that the school principal's performance has a strong impact on teachers' pedagogical competence. Another proof of how important a school principal's performance is a statement from Ekosiswoyo (2016) who stated that the leadership factor is really essential in supporting the process of upgrading education quality because style or behavioral characteristic shown in by leaders will affect and move individual or groups in the organization he/she leads. To prove the good quality of the performance of school principals, many things need to be clearly understood such as transfer skills acquisition activities that involve socialization, externalization, consolidation, and internalization of school principals, which will improve the performance of school principals to produce common goals, manage organizational resources, work together with the community, and the head of the school committee honestly (Putra et al., 2019).

However, Patimah (2018a) has her own additional attribute to the school principal's performance that has to be mastered. In her research, Patimah concluded that the relationship between emotional intelligence and the performance of the MTs Principal was affirmative and the application should be considered. Emotional intelligence is one of the skills a madrasa principal must have (Patimah, 2018b; Telegina et al., 2015). They recommend using the binary method model for optimization of regulatory and analytical functions in teaching "General pedagogy" for apprenticeships that allow teachers or prospective teachers to make progress and the outcomes of more operational learning. Arum (2017a) has different thoughts on this. Arum thought that the Development of Principal Managerial Performance Assessment Model instrument needs to be done so that the assessment of the principal really measures all measured aspects and the process of processing results is fast, thus it is necessary to improve the model of principal managerial performance assessment. Therefore, from some of the researches above and in the overall view from the 22 articles above, we can conclude that school principal's performance has a really deep impact on how teachers' pedagogical skills could develop. Not only how the principal manages the school, but also how the principal communicates, give attention professionally to teachers, paying attention to the teachers' needs in teaching, etc.

\section{Limitation and study forward}

The limitation of this research is that a principal has the biggest impact on evaluating teachers' pedagogical competence. Thus, the principal is the one responsible for developing teachers' pedagogical competence. Since this study includes many cases, further research could include performing to analyze how principal performance could affect teacher pedagogical competence. The next step in our work is to add more information of influence, forming principals is qualified in dissimilar bodies and in the variable curriculum. We truly believe that most of the role of the Principal's performance is very influential in the teacher's pedagogical competence.

\section{References}

Aiko, M. P. G. (2015). Assessment of the relationship between head-teachers' leadership styles and students' academic performance in public secondary schools in Kericho County, Kenya. Moi University.

Akhyak, M. A. (2013). Implementation of teachers pedagogy competence to optimizing learners development in public primary school in Indonesia. Journal education and research, 1(9), 113-122.

Andriani, S., Kesumawati, N., \& Kristiawan, M. (2018). The influence of the transformational leadership and work motivation on teachers performance. International Journal of Scientific \& Technology Research, 7(7), 19-29.

Andryukhina, L. M., Dneprov, S., Sumina, T. G., Zimina, E. Y., Utkina, S. N., \& Mantulenko, V. V. (2016). The model of monitoring of vocational pedagogical competences of professors in 
secondary vocational education. International Journal of Environmental and Science Education, 11(14), 7016-7034.

Arum, W. S. A. (2017a). The development of elementary school headmaster's managerial performance-assessment model based on competence standard. Paper presented at the 9th International Conference for Science Educators and Teachers (ICSET 2017).

Arum, W. S. A. (2017b). The development of elementary school headmaster's managerial performance-assessment model based on competence standard. Paper presented at the 9th International Conference for Science Educators and Teachers (ICSET 2017).

Astuty, E. (2015). Implementation analysis of lecturer's pedagogical competence on student's academic achievement. Journal of Management Research, 7(2), 152.

Bhutto, H. B., \& Dehraj, M. A. (2018). Developing process in leadership performance of secondary school head teachers in District Shaheed Benazirabad. Asian Journal of Management Sciences and Education, 7(2), 115-123.

Ekosiswoyo, R. (2016). Kepemimpinan kepala sekolah yang efektif kunci pencapaian kualitas pendidikan. Jurnal Ilmu Pendidikan, 14(2).

Hakim, A. (2015). Contribution of competence teacher (pedagogical, personality, professional competence and social) on the performance of learning. The International Journal of Engineering and Science, 4(2), 1-12.

Hariri, H., Monypenny, R., \& Prideaux, M. (2012). Principalship in an Indonesian school context: can principal decision-making styles significantly predict teacher job satisfaction? School Leadership \& Management, 32(5), 453-471.

Hariri, H., Monypenny, R., \& Prideaux, M. (2013). CORRIGENDUM Principalship in an Indonesian school context: can principal decision-making styles significantly predict teacher job satisfaction? School Leadership \& Management, 33(5), 529-529.

Hariri, H., Monypenny, R., \& Prideaux, M. (2016). Teacher-perceived principal leadership styles, decision-making styles and job satisfaction: how congruent are data from Indonesia with the Anglophile and Western literature? School Leadership \& Management, 36(1), 41-62.

Iskandar, U. (2013a). Kepemimpinan kepala sekolah dalam peningkatan kinerja guru. Jurnal Visi Ilmu Pendidikan, 10(1).

Iskandar, U. (2013b). Kepemimpinan kepala sekolah dalam peningkatan kinerja guru. Jurnal Visi Ilmu Pendidikan, 10(1), 1018-1027. doi:10.26418/jvip.v10i1.2061

Lozano, R., Merrill, M. Y., Sammalisto, K., Ceulemans, K., \& Lozano, F. J. (2017). Connecting competences and pedagogical approaches for sustainable development in higher education: A literature review and framework proposal. Sustainability, 9(10), 1889.

Makulova, A. T., Alimzhanova, G. M., Bekturganova, Z. M., Umirzakova, Z. A., Makulova, L. T., \& Karymbayeva, K. M. (2015). Theory and practice of competency-based approach in education. International Education Studies, 8(8), 183-192.

Masalimova, A., Galimova, E., \& Telegina, N. (2014). The structure and content of the model of pedagogical conditions binary approach to optimization of control and diagnostic functions in teaching "general pedagogy" to students.

Mbera, P. G. A. (2015). Relationship between leadership styles used by head teachers of public secondary schools and students' academic performance. International Journal of Academic Research in Business and Social Sciences, 5(7), 226-239.

Minadzi, V. M., \& Nyame, G. (2016). Leadership styles of basic school head teachers: how does it influence teachers' classroom performance? The International Journal of Social Sciences and Humanities Invention, 3(4), 1983-1991.

Mirzagitova, A. L., \& Akhmetov, L. G. (2015). Self-development of pedagogical competence of future teacher. International Education Studies, 8(3), 114-121.

Patimah, S. (2018a). Management performance in Islamic Senior High School education: an empirical study. European Research Studies Journal, 21(1), 165-175.

Patimah, S. (2018b). Management performance in Islamic senior high school education: An empirical study.

Pujiastuti, E., Raharjo, T. J., \& Widodo, A. T. (2012a). Kompetensi profesional, pedagogik guru IPA, persepsi siswa tentang proses pembelajaran, dan kontribusinya terhadap hasil belajar IPA di 
SMP/MTs Kota Banjarbaru. Innovative Journal of Curriculum and Educational Technology, l(1).

Pujiastuti, E., Raharjo, T. J., \& Widodo, A. T. (2012b). Kompetensi profesional, pedagogik guru IPA, persepsi siswa tentang proses pembelajaran, dan kontribusinya terhadap hasil belajar IPA di SMP/MTs Kota Banjarbaru. Innovative Journal of Curriculum and Educational Technology, 1(1), 22-29.

Purwaningsih, P. (2019). Analysis of the influence of school head leadership on teacher and business performance in SMP N 1 Baturraden Lesson Year 2018-2019. Paper presented at the International Conference of Moslem Society.

Putra, A. Y., Perizade, B., Sulastri, S., \& Hanafi, A. (2019). The knowledge transfer and the performance of the headmaster at State High Schools And State Vocational High Schools In South Sumatera Province, Indonesia. ICORE, 5(1).

Rahman, M. H. (2014). Professional competence, pedagogical competence and the performance of junior high school of science teachers. Journal of Education and Practice, 5(9), 75-80.

Sartono, S., \& Karso, K. (2020). Are the fractions difficult? A case study at Elementary School 033 Asmi. Paper presented at the International Conference on Elementary Education.

Telegina, N. V., Galimova, E. G., \& Masalimova, A. R. (2015). The structure and content of the model of pedagogical conditions binary approach to optimization of control and diagnostic functions in teaching" General pedagogy" to Students. Asian Social Science, 11(1), 364. doi:10.5539/ass.v11n1p364

Triyanto, E., Anitah, S., \& Suryani, N. (2013). Peran kepemimpinan kepala sekolah dalam pemanfaatan media pembelajaran sebagai upaya peningkatan kualitas proses pembelajaran. Jurnal Teknologi Pendidikan, 1(2), 226-238.

Wadesango, N., Gudyanga, E., \& Mberewere, M. (2015). Occupational stress among school head teachers: A case for Hwedza District secondary schools' head teachers. Journal of Social Sciences, 45(1), 31-35. 